\title{
Prediction of Possible Effects of Arsenic and Cadmium in Human Health Using Chemical-Protein and Protein-Protein Interaction Network
}

\author{
Md. Taif Ali ${ }^{1}$, Md. Ashraful Alam ${ }^{2,}$, Md. Emdad Ullah ${ }^{1}$, Mohammad Arif Ashraf ${ }^{3}$, \\ Md. Abu Sayed ${ }^{4}$, Aklima Jahan ${ }^{5}$ \\ ${ }^{1}$ Department of Biochemistry and Molecular Biology, University of Dhaka, Dhaka, Bangladesh \\ ${ }^{2}$ Department of Chemistry and Bioengineering, Iwate University, Morioka, Japan \\ ${ }^{3}$ The United Graduate School of Agricultural Sciences, Iwate University, Morioka, Japan \\ ${ }^{4}$ Department of Biochemistry and Molecular Biology, Hajee Mohammad Danesh Science and Technology University, Dinajpur, Bangladesh \\ ${ }^{5}$ Department of Chemistry, University of Chittagong, Chittagong, Bangladesh
}

Email address:

sdashraf84@yahoo.com (Md. A. Alam)

${ }^{*}$ Corresponding author

\section{To cite this article:}

Md. Taif Ali, Md. Ashraful Alam, Md. Emdad Ullah, Mohammad Arif Ashraf, Md. Abu Sayed, Aklima Jahan. Prediction of Possible Effects of Arsenic and Cadmium in Human Health Using Chemical-Protein and Protein-Protein Interaction Network. Computational Biology and Bioinformatics. Vol. 5, No. 6, 2017, pp. 74-81. doi: 10.11648/j.cbb.20170506.11

Received: July 10, 2017; Accepted: July 20, 2017; Published: November 28, 2017

\begin{abstract}
Arsenic and cadmium toxicity has demonstrated to be a crucial problem and there are many health issues interconnected with each other. The toxicity of these metals has no biological role even though remain present in some or the other form, hazardous for the human health and its proper functioning. As a result, from the very beginning, the researchers are trying to overcome the serious effects occurred by the heavy metals. The different procedures and methods are followed for minimizing the negative effects. The study was conducted to predict the probable effects and theirs targeted proteins in human body by recently developed advanced bioinformatics tools and subsequently found 10 proteins are interacted with arsenic and cadmium for each. However, these 10 proteins are independently associated with other 97 and 100 proteins. Finally, 25 common proteins have been identified which are affected by these two heavy metals. Our data mining search revealed that all of these 25 proteins are associated with the causing of cancer in human body.
\end{abstract}

Keywords: Arsenic, Cadmium, Cancer, Interaction, Heavy Metals, Human Health

\section{Introduction}

Heavy metals and their toxic forms are found in our environment due to natural and anthropogenic activities. It has toxic effects on human health exposure through foodstuff, water, air and soil [1, 2]. Heavy metals pollution in water, air, crops, vegetables and other foodstuffs is a global risk for human health $[3,4]$. Bangladesh is a developing and overpopulated country, its industrialization is increasing day by day. Most of the industries are located in Dhaka, Gazipur and Narayanganj. All these three cities are surrounded by some rivers and lake. Everyday industrial untreated and waste water is discharged to the river and the lake [5]. Subsequently, river and lake water is becoming polluted with some heavy metals like arsenic (As), cadmium (Cd) etc. Intriguingly, the recent report shows that some lake water inside and peripheral rivers water of Dhaka, Gazipur and Narayanganj have been contaminated with some heavy metals like $\mathrm{As}, \mathrm{Cd}, \mathrm{Pb}, \mathrm{Cr}, \mathrm{Hg}, \mathrm{Zn}$ [5]. These river water use for irrigation to cultivate some common agricultural crops like cereals, vegetables etc. Intriguingly, cereals and vegetables absorbed these heavy metals and subsequently contaminated. Now-a-days, it is very concerning issues that fishes, cereals and vegetables have been found toxic metals contaminated inside and surround the Dhaka city [6]. These fishes, cereals and vegetables use daily consumption in Dhaka city. Consequently, serious health problem has been occurring like cancer, 
cardiovascular disease, and diabetes etc [7, 8]. Considering above mentioned problem, our present study shows that probable proteins are being affected due to Arsenic (As) and Cadmium (Cd). We identified some common proteins by some Bioinformatics tools which are commonly responsible for some health hazards.

\section{Methods and Materials}

\subsection{Network Retrieval}

The interaction of $\mathrm{As}$ and $\mathrm{Cd}$ with human (Homo sapiens) proteins were searched through STITCH 4.0 (http://stitch.embl.de/) web server [9]. STITCH helps to predict the interactions of chemicals and proteins of specific species by evidence derived from experiments, databases and literature mining. The list of human (Homo sapiens) proteins interacting with $\mathrm{As}$ and $\mathrm{Cd}$ further considered to identify the protein-protein interaction (PPI). PPI was done through STRING 10.0 (http://string-db.org/) web server [10]. STRING is used to get all known and predicted protein interactions based on direct (physical) and indirect (functional) associations.

\subsection{Sequence Collection}

The sequences of proteins which were listed through PPI were downloaded in FASTA format for NCBI protein (http://www.ncbi.nlm.nih.gov/protein) database. The repetition was avoided during sequence collection. All the downloaded protein sequences were kept in one FASTA file for further analysis.

\subsection{Blast 2 GO}

Gene ontology of these sequences was done through Blast 2 GO software [11]. This tool was used for functional annotation and analysis of protein sequences. The correlation of sequences in biological process, molecular function and presence in cellular component were analyzed.

\subsection{Venny}

We used Venny (http://bioinfogp.cnb.csic.es/tools/venny/) web server to detect the common proteins in four targeted list. And the list of common protein was also collected from here.

\section{Results}

\subsection{Interaction Prediction}

In our study, we found 10 potential proteins of Homo sapiens have been predicted by STITCH 4.0 for As and Cd (Figure 1), respectively. During protein-protein interaction (PPI) prediction by STRING 10.0 bioinformatics tools 97,100 proteins have been identified for As and Cd (Table 1 and 2), respectively.

a

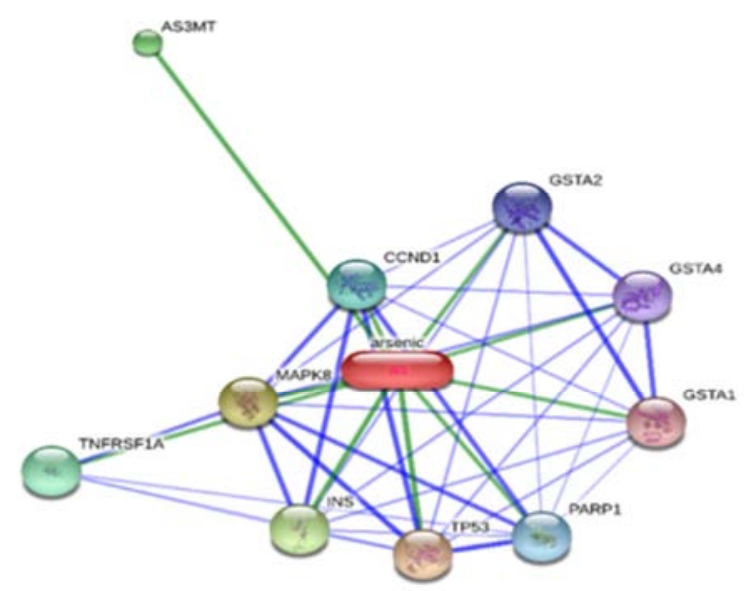

b

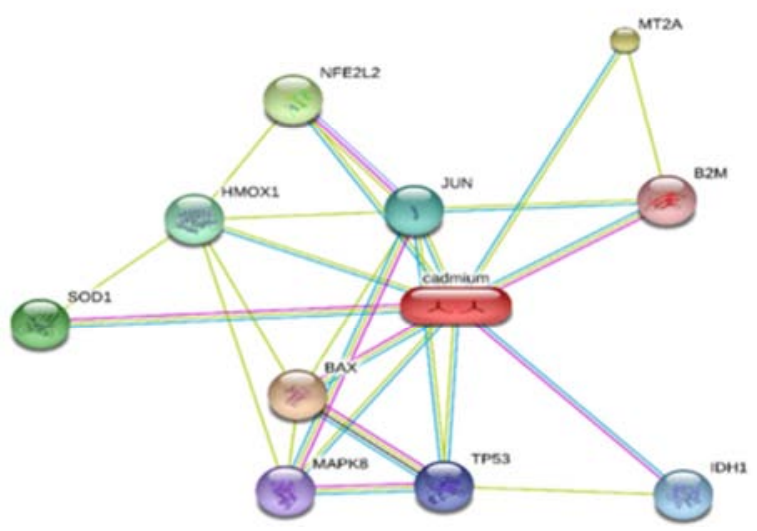

Figure 1. Interaction of (a) arsenic and (b) cadmium with targeted proteins of Homo sapiens predicted through STITCH 4.0. 
Table 1. Interaction of Arsenic and Proteins found by using STITCH and STRING tools.

\begin{tabular}{|c|c|c|c|c|c|c|c|c|c|c|}
\hline STITCH & TP 53 & МАРК 8 & INS & AS 3 MT & TNFRSF 1 A & CCND 1 & PARP 1 & GSTA 2 & GSTA 4 & GSTA 1 \\
\hline \multirow{9}{*}{ STRING } & & JUN & INSR & GSTO 1 & TRADD & CDK 4 & XRCC 1 & GSTM 5 & GSTM 2 & GSTA 2 \\
\hline & CDKN $1 \mathrm{~A}$ & ATF 2 & IRS 1 & MMD & TRAF 2 & CDK 6 & TP 53 & GSTA 1 & GSTM 3 & CYP 1 A 1 \\
\hline & ATM & TP 53 & IRS 2 & GSTO 2 & RIPK 1 & CDKN $1 \mathrm{~A}$ & PCNA & NFE 2 L 2 & GSTM 1 & GSTM 5 \\
\hline & SIRT 1 & MAP 2 K 4 & PDX 1 & C 10 orf 32 & BIRC 1 & RB 1 & CASP 3 & GSTA 4 & GSTM 4 & CYP 1 A 2 \\
\hline & BRCA 1 & MAPK 8 IP 1 & AKT 1 & CNNM 2 & FADD & CDKN 1 B & XRCC 5 & GSTT 1 & GSTM 5 & GSTT 2 B \\
\hline & KAT 2 B & JUND & IGF 1 & WBP $1 \mathrm{~L}$ & TNFRSF $1 \mathrm{~B}$ & UBC & XRCC 6 & GSTO 1 & GSTT 1 & MGST 3 \\
\hline & MAPK 8 & IRS 1 & IGFBP 1 & C 2 orf 82 & IKBKB & CDK 2 & PARG & GSTM 1 & GSTO 1 & GSTO 1 \\
\hline & EP 300 & MAP 2 K 7 & IGF $1 \mathrm{R}$ & & BIRC 2 & STAT 3 & UBC & GSTT 2 B & GSTT 2 B & CYP 1 B 1 \\
\hline & CREBBP & FOS & FOXO 1 & & TRAF 1 & PCNA & CASP 7 & CYP 1 A 1 & GSTA 2 & GSTT 1 \\
\hline
\end{tabular}

Table 2. Interaction of Cadmium and Proteins found by using STITCH and STRING tools.

\begin{tabular}{|c|c|c|c|c|c|c|c|c|c|c|}
\hline STITCH & BAX & MT 2 A & NFE 2 L 2 & SOD 1 & HMOX 1 & JUN & IDH 1 & TP 53 & МАРК 8 & B 2 M \\
\hline \multirow{9}{*}{ STRING } & BCL 2 L 1 & FOS & KEAP 1 & UBC & JUN & FOS & IDH $3 \mathrm{~A}$ & MDM 2 & JUN & HLA-A \\
\hline & BCL 2 & JUN & UBC & SOD 2 & HIF $1 \mathrm{~A}$ & MAPK 8 & IDH 3 B & CDKN $1 \mathrm{~A}$ & ATF 2 & HFE \\
\hline & MCL 1 & B $2 \mathrm{M}$ & EIF 2 AK 3 & GPX 1 & BLVRA & ATF 3 & ACLY & ATM & TP 53 & HLA-C \\
\hline & BCL 2 L 11 & IRF 1 & CUL 3 & PRDX 1 & USF 2 & MAPK 9 & $\mathrm{ACO} 2$ & SIRT 1 & MAP 2 K 4 & $\mathrm{CD} 8 \mathrm{~A}$ \\
\hline & TP 53 & HLA-DRB 5 & GSTA 2 & $\mathrm{CCS}$ & BLVRB & MAPK 10 & $\mathrm{ACO} 1$ & BRCA 1 & MAPK 8 IP 1 & CD $1 \mathrm{D}$ \\
\hline & XRCC 6 & ICAM 1 & MAFG & CAT & AKT 1 & FOSL 1 & OGDHL & KAT 2 B & JUND & MR 1 \\
\hline & BID & GBP 1 & MAFK & PRDX 2 & NFE 2 L 2 & ATF 2 & GOT 2 & CREBBP & IRS 1 & FCGRT \\
\hline & VDAC 1 & HLA-B & JUN & TXN & MAPK 14 & SMAD 3 & MDH 1 & MAPK 8 & MAP $2 \mathrm{~K} 7$ & HLA-B \\
\hline & BAK 1 & CD 44 & MAFF & GPX 2 & FOS & FOSL 2 & GLUD 1 & EP 300 & FOS & CALR \\
\hline
\end{tabular}

\subsection{Pathway Detection}

Through Blast 2 GO software, we did following steps for a list of target protein sequences: protein Blast, mapping, retrieving Enzyme Codes (EC), tracking KEGG pathways and scanning motifs by Inter Pro Scan. These accomplished jobs helped to generate an overview of biological process, molecular function and cellular component of these listed proteins for As and Cd (Figure 2-4) and Cd (Figure 5).

a

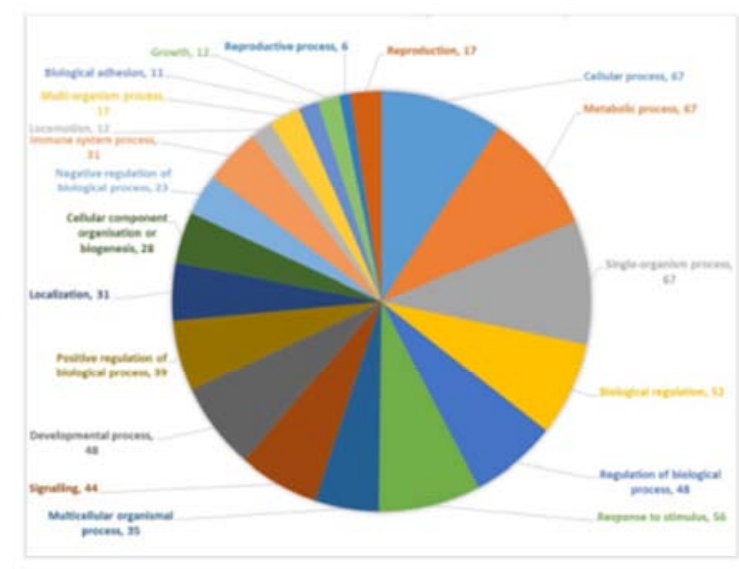

b

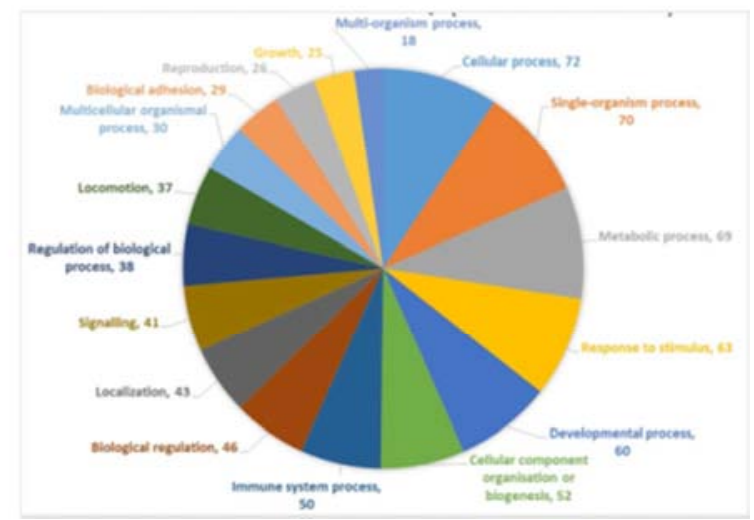

Figure 2. Interaction of (a) arsenic and (b) cadmium with targeted proteins of Homo sapiens involved in function with biological process. 
Md. Taif Ali et al.: Prediction of Possible Effects of Arsenic and Cadmium in Human Health Using Chemical-Protein and Protein-Protein Interaction Network

a

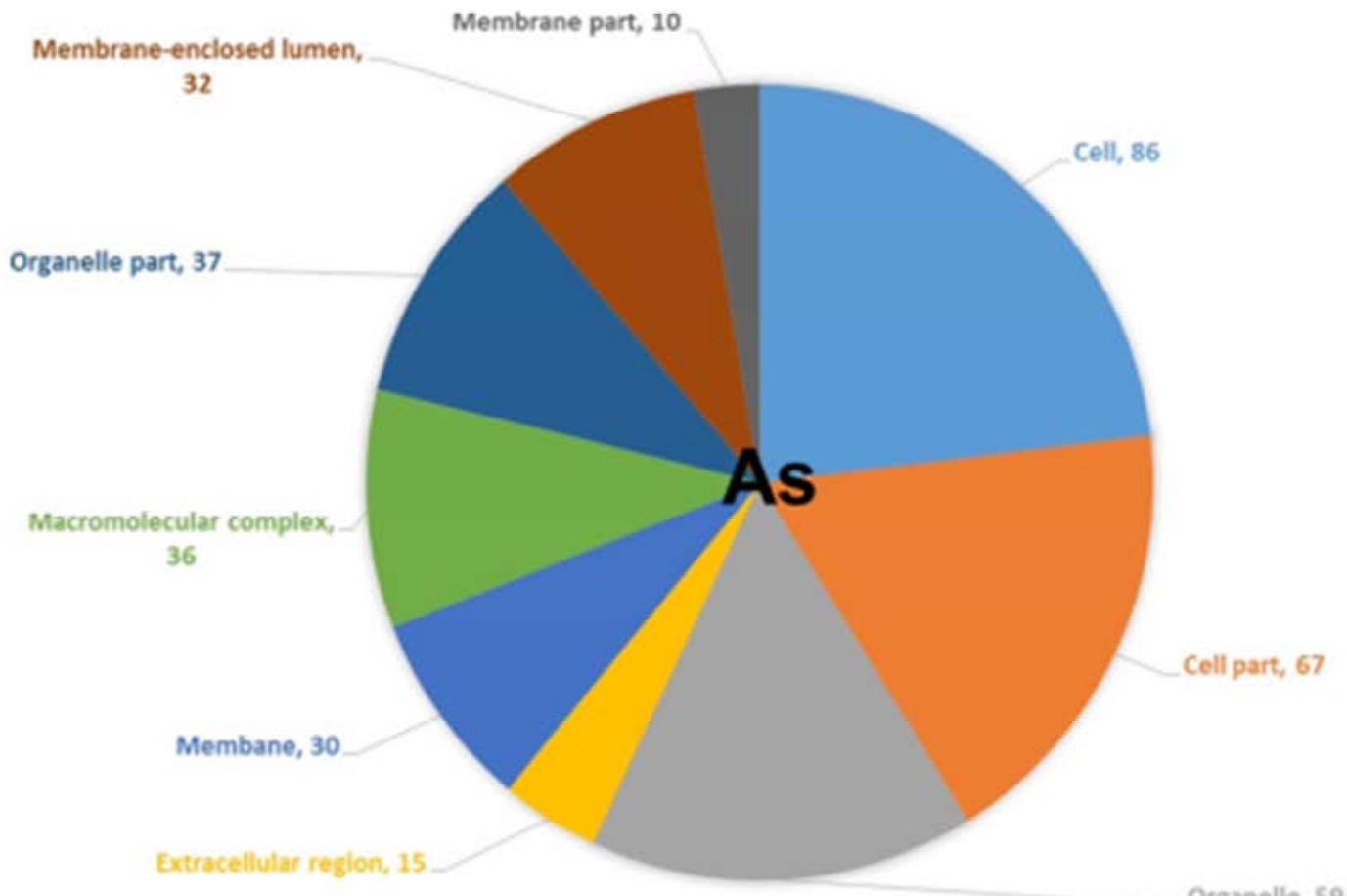

Organelle, 59

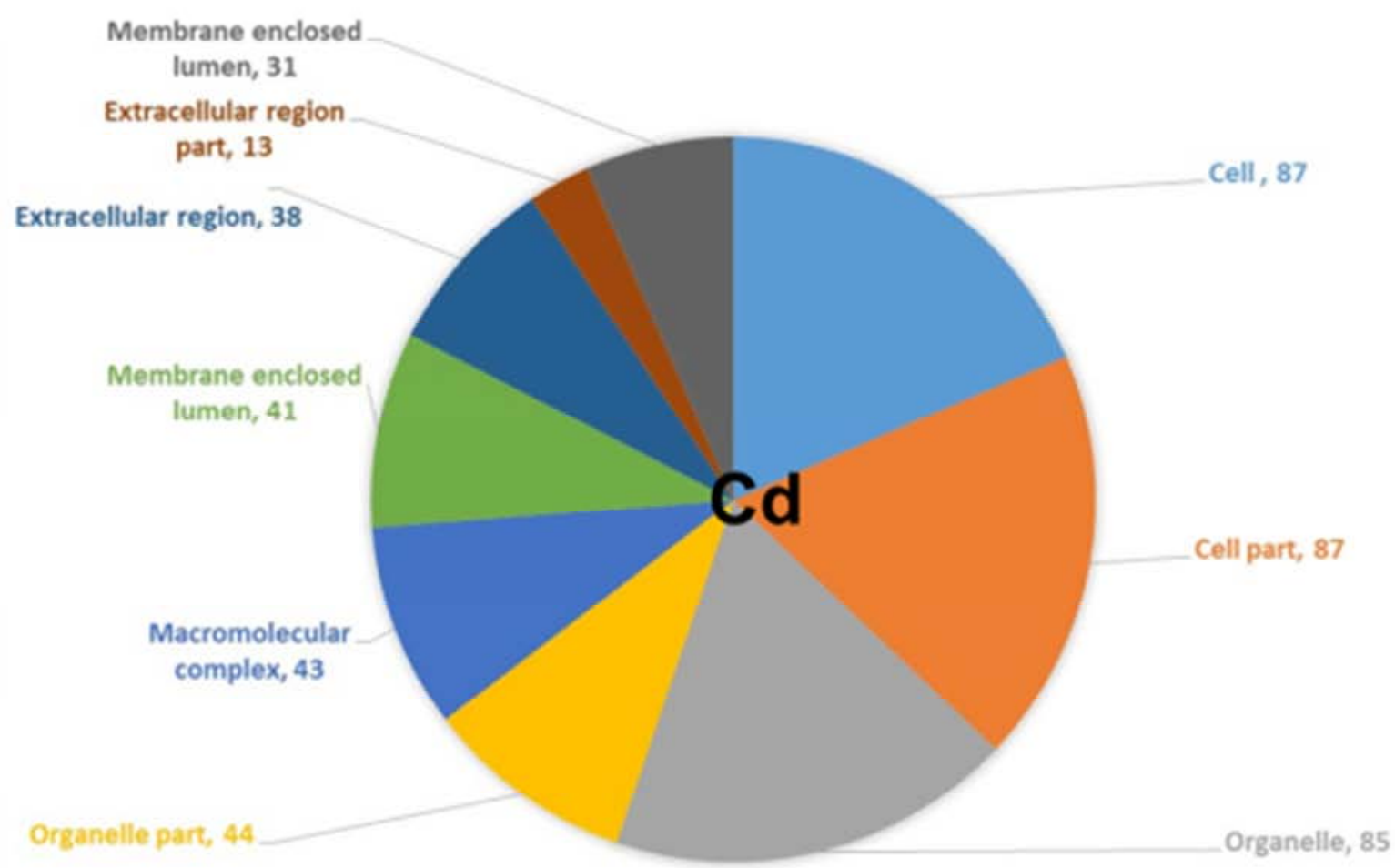

Figure 3. Interaction of (a) arsenic and (b) cadmium with targeted proteins of Homo sapiens involved in function with cell component. 
a

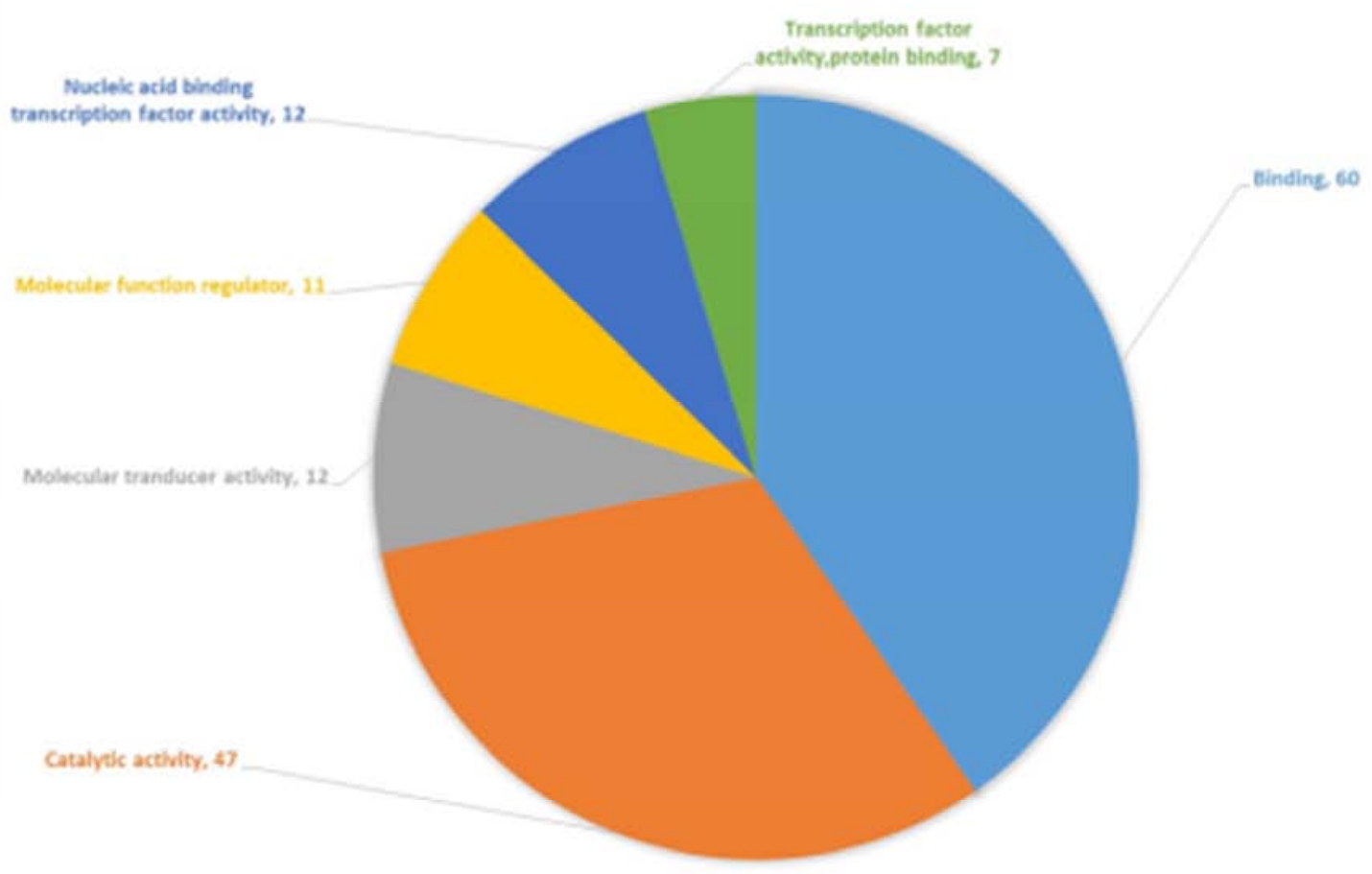

b

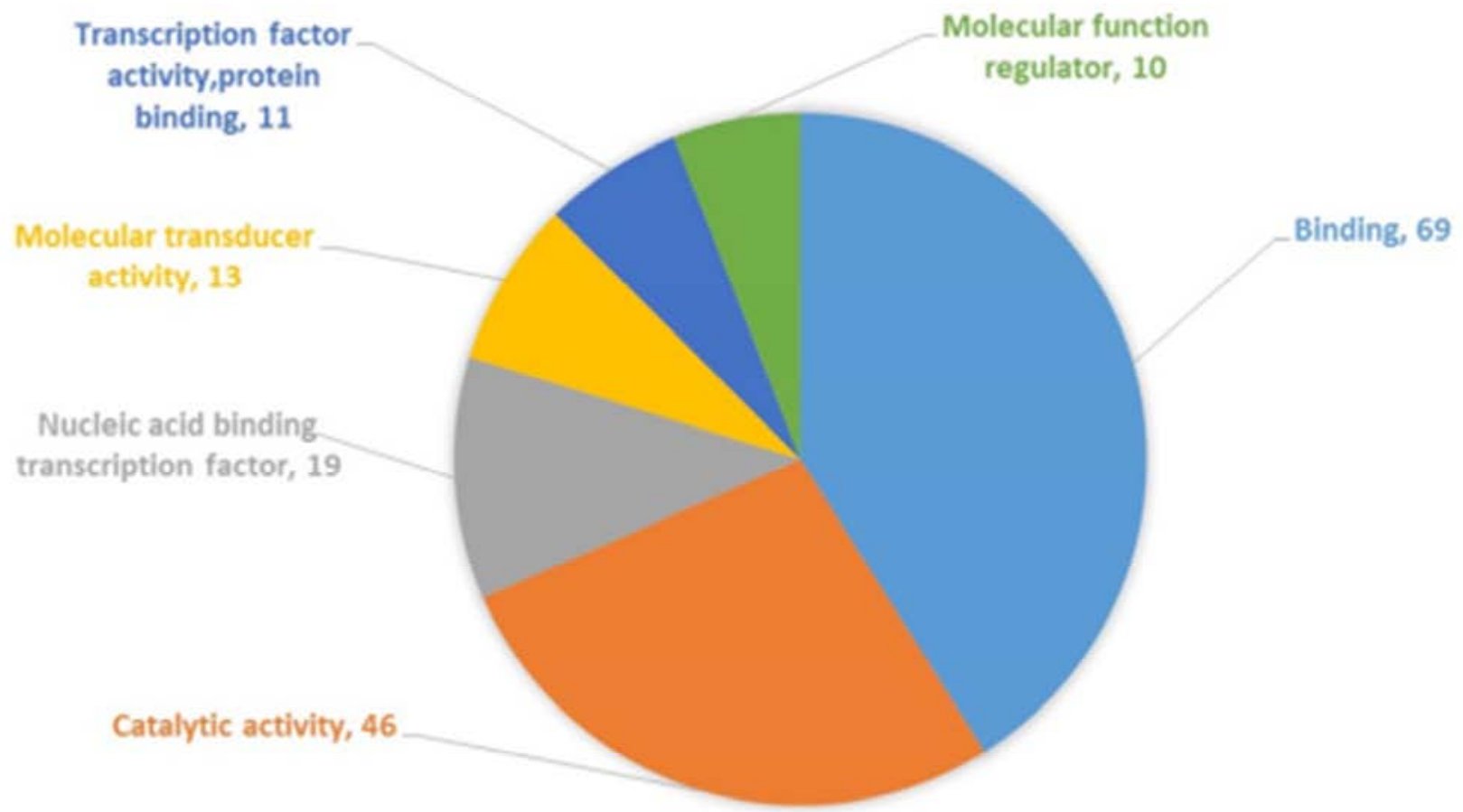

Figure 4. Interaction of (a) arsenic and (b) cadmium with targeted proteins of Homo sapiens involved in with cell function. 


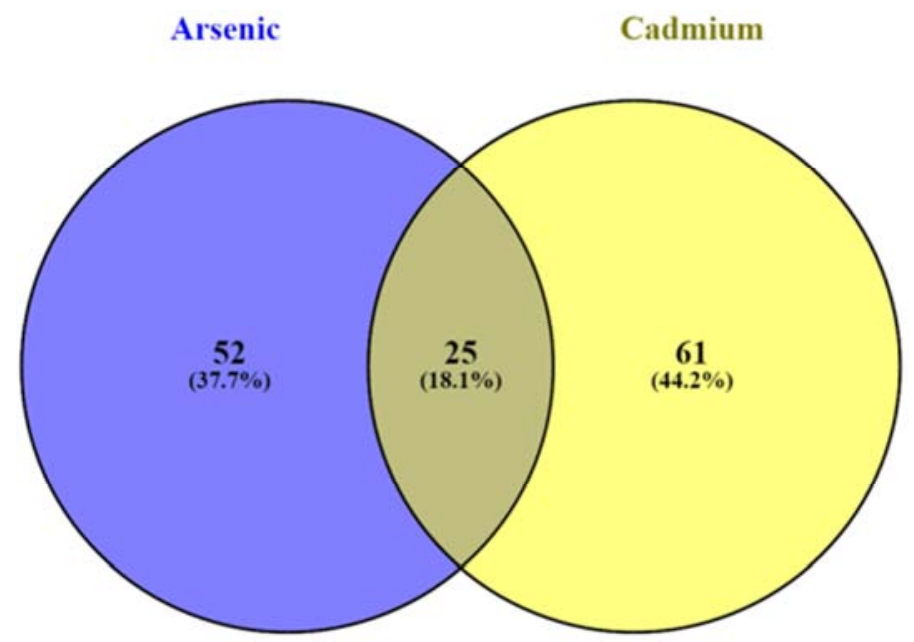

Figure 5. Identification of common targeted proteins of Homo sapiens trough venny web server.

\subsection{Common Targets Determination}

These two heavy metals As and Cd have multiple targets and our study showed that 25 proteins (Table 3 ) are common target with As and Cd which was screened by Venny web server (Figure 5).

Table 3. Enlisted of the common proteins with their effects on human health due to toxic effects of Arsenic and Cadmium.

\begin{tabular}{|c|c|c|c|}
\hline Name & Short Descriptions & Functions & References \\
\hline BCL 2 & Apoptosis regulator Bcl-2 & $\begin{array}{l}\text { Its role in regulation of apoptotic signaling pathways, is possibly } \\
\text { related to carcinogenesis }\end{array}$ & [15] \\
\hline TP 53 & Cellular tumor antigen p53 & Cell cycle regulation & [16] \\
\hline XRCC 6 & X-ray repair cross-complementing protein 6 & $\begin{array}{l}\text { Function as scaffolding protein in base excision repair and single } \\
\text { strand break repair pathways. }\end{array}$ & [17] \\
\hline FOS & Proto-oncogene c-Fos & $\begin{array}{l}\text { A variety of biological processeses, including pro- liferation, } \\
\text { differentiation, tumorigenesis, and apoptosis. }\end{array}$ & [18] \\
\hline JUN & Transcription factor AP-1 & An important role in melanoma progression and development. & [19] \\
\hline GSTA 2 & Glutathione S-transferase A2 & $\begin{array}{l}\text { Upregulated during oxidative stress, overexpressed in many tumors } \\
\text { and leading to causes during cancer chemotherapy }\end{array}$ & [20] \\
\hline AKT 1 & RAC-alpha serine/threonine-protein kinase & Inhibits the apoptosis & [21] \\
\hline NFE2 L 2 & $\begin{array}{l}\text { Nuclear factor erythroid 2-related factor } 2 \text { (No } \\
\text { cancer related, blood heaomorrhage) }\end{array}$ & Inflammatory disorder & [22] \\
\hline ATF 2 & $\begin{array}{l}\text { Cyclic AMP-dependent transcription factor ATF-2 } \\
\text { (Pregnancy related) }\end{array}$ & Function in the control of uterine activity throughout pregnancy. & [23] \\
\hline MAPK 8 IP 1 & C-Jun-amino-terminal kinase-interacting protein 1 & Causing of Alzheimer's disease. & [24] \\
\hline JUND & Transcription factor jun-D & $\begin{array}{l}\text { Interact with tumor suppressor gene } M E N 1 \text { encoded by nuclear } \\
\text { protein menin }\end{array}$ & [25] \\
\hline IRS 1 & Insulin receptor substrate 1 & Cell proliferation and differentiation. & [26] \\
\hline MAP 2 K 7 & $\begin{array}{l}\text { Dual specificity mitogen-activated protein kinase } \\
\text { kinase } 7\end{array}$ & $\begin{array}{l}\text { Decreased expression of MAP } 2 \mathrm{~K} 7 \text { and causes schizophrenia is a } \\
\text { mental illness }\end{array}$ & [27] \\
\hline MAP 2 K 4 & Protein Map 2 k 4 & Human prostate cancer metastasis & [28] \\
\hline MDM 2 & E 3 ubiquitin-protein ligase $\mathrm{Mdm} 2$ & $\begin{array}{l}\text { MDM } 2 \text { impairs all-trans retinoic acid induced osteoblastic } \\
\text { differentiation in osteosarcoma cells and primary osteosarcoma } \\
\text { blasts }\end{array}$ & [29] \\
\hline CDKN $1 \mathrm{~A}$ & Cyclin-dependent kinase inhibitor $1 \mathrm{~A}$ & Modulates cell cycle, apoptosis, senescence and cell differentiation & [30] \\
\hline ATM & Serine-protein kinase ATM & $\begin{array}{l}\text { Regulating the cellular response to } \\
\text { genotoxic stress }\end{array}$ & [31] \\
\hline SIRT 1 & NAD-dependent protein deacetylase sirtuin-1 & $\begin{array}{l}\text { An important regulator in cellular stress response and energy } \\
\text { metabolism. }\end{array}$ & [32] \\
\hline BRCA 1 & Breast cancer type 1 susceptibility protein & Causes breast cancer & [33] \\
\hline KAT 2 B & Histone acetyltransferase KAT 2 B & Alterations in human abdominal aortic aneurysm & [34] \\
\hline MAPK 8 & Mitogen-activated protein kinase 8 & $\begin{array}{l}\text { Participate in a diverse array of cellular programs, including cell } \\
\text { differentiation, cell movement, cell division, and cell death }\end{array}$ & [35] \\
\hline CDKN 2 A & Cyclin-dependent kinase inhibitor $2 \mathrm{~A}$ & Causes salivary gland carcinomas & [36] \\
\hline EP 300 & Histone acetyltransferase p 300 & Alzheimer's Disease & [37] \\
\hline CREBBP & CREB-binding protein & $\begin{array}{l}\text { Participate in the activities of hundreds of different transcription } \\
\text { factors }\end{array}$ & [38] \\
\hline UBC & Polyubiquitin-C & $\begin{array}{l}\text { Responsive gene to cellular treats such as UV irradiation, heat } \\
\text { shock, oxidative stress and translational impairment }\end{array}$ & [39] \\
\hline
\end{tabular}




\section{Discussion}

Heavy metals are always toxic to animal health in higher doses. Among the heavy metals As is one of most dangerous health hazard to human as because every fourth of the tube well is polluted with As in Bangladesh [12]. In addition that both of $\mathrm{As}$ and $\mathrm{Cd}$ polluted river and lake water is barning issues in Dhaka, Gazipur and Naraynagnj cities [13]. As a result, some life threatening diseases like cancer, metabolic disorders are common in Bangladesh. We found that some proteins are directly and indirectly affected by $\mathrm{As}$ and $\mathrm{Cd}$ and subsequently, life threatening diseases have been occurred. However, molecular mechanism of heavy metals has been extensively reported that oxidative DNA damage, inhibition of major DNA repair systems and inactivation of tumor suppressor genes are the main causes for increasing the health problem in human due to exposure of heavy metals [14]. Considering all of these preliminary published data, we investigated the target proteins for As and $\mathrm{Cd}$ which have been affected in human body by recent Bioinformatics tools. In our present study, we found total 25 common proteins for As and $\mathrm{Cd}$ enlisted in tabular form with their short description and probable functions which have the possibility to affect in the human body (Table 3). Interestingly, most of the identified proteins are responsible for occurring the cancer in the human body. For example, Apoptosis regulator $\mathrm{Bcl}-2$ protein family was expressed in many types of cancer cell and related to cancer pathophysiology [15].

\section{Conclusions}

Effects of heavy metals such as As and Cd on living organism specially human beings is not constant in any locations, hence it is varies due to exposure in environment. Proper guidelines, government policy, rules can be reduced the level of contamination of heavy metals to be made safe and healthy living area for living organisms. Professional discharge to heavy metals can be declined by engineering solutions. Surveilling the exposure and possible intercession for decreasing additional exposure to heavy metals in the environment and in humans can become a momentous step towards prevention. National as well as international co-operation can play a vital role for framing appropriate tactics to prevent heavy metal toxicity.

\section{Conflict of Interest}

The authors have declared no conflict of interest with any parties which may arise from this publication.

\section{Acknowledgements}

The authors are grateful to the department of Biochemistry and Molecular Biology, University of Dhaka, Bangladesh.

\section{References}

[1] Mudgal V, Madaan N, Mudgal A, Singh RB, Mishra S. Effect of Toxic Metals on Human Health. Open Nutraceuticals J. 2010; 3: 94-99. doi: 10.2174/1876396001003010094.

[2] Nagajyoti PC, Lee KD, Sreekanth TVM. Heavy metals, occurrence and toxicity for plants: A review. Environ Chem Lett. 2010; 8: 199-216. doi: 10.1007/s10311-010-0297-8.

[3] Guerra F, Trevizam AR, Muraoka T, Marcante NC, CaniattiBrazaca SG. Heavy metals in vegetables and potential risk for human health. Sci Agric. 2012; 69: 54-60. doi: 10.1590/S0103-90162012000100008.

[4] Fernández-Luqueño F, López-Valdez F, Gamero-Melo P, Luna-Suárez S, Aguilera-González E, Martínez A, et al. Heavy metal pollution in drinking water - a global risk for human health: A review. African J Environ Sci Technol. 2013; 7: 567-584. doi: 10.5897/AJEST12.197.

[5] Biswas SK, Rahman MM, Bahar MA-U, Debnath S. Status of heavy metal in the peripheral rivers around Dhaka city. OIDA Int J Sustain Dev. 2015; 8: 39-44.

[6] Ahmad JU, Goni MA. Heavy metal contamination in water, soil, and vegetables of the industrial areas in Dhaka, Bangladesh. Environ Monit Assess. 2010; 166: 347-357. doi: 10.1007/s10661-009-1006-6.

[7] Islam MS, Hoque MF. Concentrations of heavy metals in vegetables around the industrial area of Dhaka city, Bangladesh and health risk assessment. Int Food Res J. 2014; 21: $2121-2126$.

[8] Islam MS, Ahmed MK, Habibullah-Al-Mamun M. Determination of Heavy Metals in Fish and Vegetables in Bangladesh and Health Implications. Hum Ecol Risk Assess An Int J. 2014; 21: 986-1006. doi: 10.1080/10807039.2014.950172.

[9] Kuhn M, Szklarczyk D, Pletscher-Frankild S, Blicher TH, Von Mering C, Jensen LJ, et al. STITCH 4: Integration of proteinchemical interactions with user data. Nucleic Acids Res. 2014; 42: 401-407. doi: 10.1093/nar/gkt1207.

[10] Szklarczyk D, Franceschini A, Wyder S, Forslund K, Heller $\mathrm{D}$, Huerta-Cepas J, et al. STRING v 10: Protein-protein interaction networks, integrated over the tree of life. Nucleic Acids Res. 2015; 43: D 447-D 452. doi: 10.1093/nar/gku1003.

[11] Conesa A, G??tz S, Garc??a-G??mez JM, Terol J, Tal??n M, Robles M. Blast 2 GO: A universal tool for annotation, visualization and analysis in functional genomics research. Bioinformatics. 2005; 21: 3674-3676. doi: 10.1093/bioinformatics/bti610.

[12] Atkins PJ, Hassan MM, Dunn CE. Toxic torts: Arsenic poisoning in Bangladesh and the legal geographies of responsibility. Trans Inst Br Geogr. 2006; 31: 272-285. doi: 10.1111/j.1475-5661.2006.00209.x.

[13] Biswas SK, Rahman MM, Bahar MA-U, Debnath S. Status of heavy metal in the peripheral rivers around dhaka city. OIDA Int Sustain Dev. 2015; 8: 39-44. 
[14] Beyersmann D, Hartwig A. Carcinogenic metal compounds: Recent insight into molecular and cellular mechanisms. Arch Toxicol. 2008; 82: 493-512. doi: 10.1007/s00204-008-0313-y.

[15] Tzifi F, Economopoulou C, Gourgiotis D, Ardavanis A, Papageorgiou S, Scorilas A. The role of BCL 2 family of apoptosis regulator proteins in acute and chronic leukemias. Adv Hematol. 2012; 2012. doi: 10.1155/2012/524308.

[16] Zakut-Houri R, Bienz-Tadmor B, Givol D, Oren M. Human p 53 cellular tumor antigen: cDNA sequence and expression in COS cells. EMBO J. 1985; 4: 1251-5. Available: http://www.pubmedcentral.nih.gov/articlerender.fcgi?artid=55 4332 andtool $=$ pmcentrezandrendertype $=$ abstract.

[17] Hanssen-Bauer A, Solvang-Garten K, Akbari M, Otterlei M. $\mathrm{X}$-ray Repair Cross Complementing protein 1 in base excision repair. Int J Mol Sci. 2012; 13: 17210-17229. doi: $10.3390 /$ ijms 131217210 .

[18] Elkeles a, Juven-Gershon T, Israeli D, Wilder S, Zalcenstein a, Oren M. The c-fos proto-oncogene is a target for transactivation by the p 53 tumor suppressor. Mol Cell Biol. 1999; 19: 2594-2600.

[19] Kappelmann M, Bosserhoff A, Kuphal S. AP-1/c-Jun transcription factors: Regulation and function in malignant melanoma. Eur J Cell Biol. Elsevier GmbH.; 2014; 93: 76-81. doi: 10.1016/j.ejcb.2013.10.003.

[20] Daniel W. Nebert and Vasilis Vasiliou. Analysis of the glutathione S-transferase (GST) gene family. Hum Genomics. 2004; 1: 60-64.

[21] Chaudhary V. Structure based inhibitor designing for RACalpha serine/threonine-protein kinase in human. J Adv Bioinforma Appl Res. 2012; 3: 374-378.

[22] Kim J, Cha YN, Surh YJ. A protective role of nuclear factorerythroid 2-related factor-2 (Nrf 2) in inflammatory disorders. Mutat Res - Fundam Mol Mech Mutagen. Elsevier B. V.; 2010; 690: 12-23. doi: 10.1016/j.mrfmmm.2009.09.007.

[23] Bailey J, Sparey C, Phillips RJ, Gilmore K, Robson SC, Dunlop W, et al. Expression of the cyclic AMP-dependent transcription factors, CREB, CREM and ATF 2, in the human myometrium during pregnancy and labour. Mol Hum Reprod. 2000; 6: 648-660. doi: 10.1093/molehr/6.7.648.

[24] Vagnoni A, Glennon EBC, Perkinton MS, Gray EH, Noble W, Miller CCJ. Loss of c-Jun N-terminal kinase-interacting protein-1 does not affect axonal transport of the amyloid precursor protein or $\mathrm{A} \beta$ production. Hum Mol Genet. 2013; 22: 4646-4652. doi: $10.1093 / \mathrm{hmg} / \mathrm{ddt} 313$.

[25] Agarwal SK, Guru SC, Heppner C, Erdos MR, Collins RM, Park SY, et al. Menin interacts with the AP 1 transcription factor JunD and represses JunD-activated transcription. Cell. 1999; 96: 143-152. doi: 10.1016/S0092-8674 (00) 80967-8.

[26] Chen J, Capozza F, Wu A, Deangelis T, Sun H, Lisanti M, et al. Regulation of insulin receptor substrate-1 expression levels by caveolin-1. J Cell Physiol. 2008; 217: 281-289. doi: $10.1002 / j \mathrm{jcp} .21498$.

[27] Winchester CL, Ohzeki H, Vouyiouklis DA, Thompson R, Penninger JM, Yamagami K, et al. Converging evidence that sequence variations in the novel candidate gene MAP $2 \mathrm{~K} 7$ (MKK 7) are functionally associated with schizophrenia. Hum Mol Genet. 2012; 21: 4910-4921. doi: 10.1093/hmg/dds331.

[28] Pavese JM, Ogden IM, Voll EA, Huang X, Xu L, Jovanovic B, et al. Mitogen-activated protein kinase kinase 4 (MAP 2 K 4) promotes human prostate cancer metastasis. PLoS One. 2014; 9: 1-12. doi: 10.1371/journal.pone.0102289.

[29] Ying M, Zhang L, Zhou Q, Shao X, Cao J, Zhang N, et al. The E 3 ubiquitin protein ligase MDM 2 dictates all-trans retinoic acid-induced osteoblastic differentiation of osteosarcoma cells by modulating the degradation of RAR $\alpha$. Oncogene. 2016; $1-$ 10. doi: 10.1038/onc.2015.503.

[30] Ouellet S, Vigneault F, Lessard M, Leclerc S, Drouin R, Guérin SL. Transcriptional regulation of the cyclin-dependent kinase inhibitor $1 \mathrm{~A}(\mathrm{p} 21)$ gene by NFI in proliferating human cells. Nucleic Acids Res. 2006; 34: 6472-6487. doi: 10.1093/nar/gk1861.

[31] Shiloh Y, Ziv Y. The ATM protein kinase: regulating the cellular response to genotoxic stress, and more. Nat Rev Mol Cell Biol. Nature Publishing Group; 2013; 14: 197-210. doi: $10.1038 / \mathrm{nrm} 3546$.

[32] Guo X, Kesimer M, Tolun G, Zheng X, Xu Q, Lu J, et al. The NAD (+)-dependent protein deacetylase activity of SIRT1 is regulated by its oligomeric status. Sci Rep. 2012; 2: 640. doi: $10.1038 /$ srep00640.

[33] Petrucelli N, Daly MB, Feldman GL. Hereditary breast and ovarian cancer due to mutations in BRCA1 and BRCA2. Genet Med. 2010; 12: 245-259. doi: $10.1097 /$ GIM.0b013e3181d38f2f.

[34] Han Y, Tanios F, Reeps C, Zhang J, Schwamborn K, Eckstein $\mathrm{HH}$, et al. Histone acetylation and histone acetyltransferases show significant alterations in human abdominal aortic aneurysm. Clin Epigenetics. Clinical Epigenetics; 2016; 8: 3. doi: 10.1186/s13148-016-0169-6.

[35] Schaeffer HJ, Weber MJ. Mitogen-activated protein kinases: specific messages from ubiquitous messengers. Mol Cell Biol. 1999; 19: 2435-2444. doi: 10.1128/MCB.19.4.2435.

[36] Senft E, Lemound J, Stucki-Koch A, Gellrich N-C, Kreipe H, Hussein K. Expression of cyclin-dependent kinase inhibitor 2 A 16, tumour protein 53 and epidermal growth factor receptor in salivary gland carcinomas is not associated with oncogenic virus infection. Int $\mathrm{J}$ Oral Sci. 2014; 7: 18-22. doi: 10.1038/ijos.2014.28.

[37] Lu X, Deng Y, Yu D, Cao H, Wang L, Liu L, et al. Histone acetyltransferase p 300 mediates histone acetylation of PS 1 and BACE 1 in a cellular model of Alzheimer's disease. PLoS One. 2014; 9: 1-9. doi: 10.1371/journal.pone.0103067.

[38] Vo N, Goodman RH. CREB-binding Protein and p 300 in Transcriptional Regulation. J Biol Chem. 2001; 276: 1350513508. doi: 10.1074/jbc.R 000025200.

[39] Radici L, Bianchi M, Crinelli R, Magnani M. Ubiquitin C gene: Structure, function, and transcriptional regulation. Adv Biosci Biotechnol. 2013; 4: 1057-1062. doi: 10.4236/abb.2013.412141 